\title{
FORMATION FEATURES OF TUBULAR PRODUCTS ON THE BASIS OF COMPOSITE HYDROGELS
}

\author{
Oleh Suberlyak ${ }^{1}$, Oleksandr Grytsenko ${ }^{1,}{ }^{凶}$, Nataliia Baran $^{1}$, \\ Galyna Yatsulchak ${ }^{1}$, Bohdan Berezhnyy ${ }^{1}$
}

https://doi.org/10.23939/chcht14.03.312

\begin{abstract}
The method for obtaining composite hydrogel tubular products with the increased strength on the basis of copolymers of 2-hydroxyethylmethacrylate with polyvinylpyrrolidone has been developed. The method consists in the formation of hydrogel tubes with a subsequent precipitation from the solution into their outer surfa with polyvinylpyrrolidone. The obtained composite hydrogel tubes are characterized by the sufficient strength, resilience, elasticity, as well as the ability to withstand an internal pressure within $24-43 \mathrm{kPa}(180-320 \mathrm{~mm} \mathrm{Hg})$.
\end{abstract}

Keywords: hydrogels, hydrogel composites, polyamide, polyvinylpyrrolidone, vascular prostheses.

\section{Introduction}

Blood vessel prostheses are implanted devices, which function in the human body in constant contact with the blood. Preferably, the patient's own vessels removed from other parts of the body are used for this purpose. Creation of synthetic materials for the production of samples of vascular prostheses and implants with improved properties is an urgent task, which is caused by the deficiency of healthy vessels to replace the affected areas of arteries and veins [1].

Unlike most synthetic products, which are used in medicine, blood vessel prostheses are developing to be as close to natural vessels as possible by its characteristics. It should be noted that nowadays, none of the synthetic prostheses is perfect and has a number of disadvantages. For the purpose of use, a large variety of synthetic textile fibers including Ivalon, Orlon, Nylon and Dacron, as well as non-textile materials (Teflon) have been tested for prosthetic applications [2]. However, studies have shown that vessels based on these materials lead to occur various complications, associated with structural defects such as lack of compliance, dilatation and resistance to the blood

\footnotetext{
${ }^{1}$ Lviv Polytechnic National University,

12, S. Bandery St., 79013 Lviv, Ukraine

ogryts@gmail.com

(c) Suberlyak O., Grytsenko O., Baran N., Yatsulchak G., Berezhnyy B., 2020
}

and obstruction. Nowadays, the textile watertight implants of polyethylene terephthalate (PET) share the market of vascular prostheses with those one-piece implants, moulded from polytetrafluoroethylene (PTFE) [2]. Biocompatibility, biostability and high tensile strength of prostheses based on PET, used for a long time during exploitation have long-been well documented [3]. In medical practice, polyurethane prostheses are used as well [4]. However, synthetic prostheses of synthetic materials are non-durable during the exploitation due to thrombosis and insufficient healing process [5].

Therefore, the question of developing new vascular prostheses and simple technologies for their production remains open, and researches related to its solution need to be continued. This task is in the area of interests not only of vascular surgeons, but also of researchers in the field of chemistry, mechanics, biotechnology, etc.

Due to their unique properties [6-8], polymer hydrogels are seen as perspective materials for the production of vascular protheses. Polymer hydrogels are obtained through high hydrophilic cross-linked polymers saturation by water. As a rule during swelling the physical transfer from glassy state into high elasticity one is observed. As a result of this hydrogels are characterized by a high sorption ability relative to low-molecular substances, penetrability for liquids and gases, and this is the main reason for their usage in different branches of science and industry.

Materials based on copolymers of 2-hydroxyethylmethacrylate (HEMA) with polyvinylpyrrolidone (PVP), developed at Lviv Polytechnic National University in the Department of Chemical Technology of Plastics Processing [9-12] are particularly noteworthy. HEMA was selected as the main component of the hydrogel network due to its solubility in water, as well as the presence of a carbonyl group that is able to coordinate various compounds [13]. Poly(2-hydroxyethyl methacrylate) (pHEMA) and its copolymers are characterized by a high degree of water-absorption, ability to adsorb low molecular weight substances, high biocompatibility and low thrombogenicity [14-16]. PVP has drawn a great attention due to its unique properties such as biocom- 
patibility, non-toxicity, solubility in water and in many organic solvents, $\mathrm{pH}$ stability, affinity for both hydrophobic and hydrophilic complex substances, as well as chemical inertness in physiological reactions [17]. The use of PVP opens additional opportunities during the obtaining and stabilizing nanopowders of metals [18, 19], modifying various substances and materials [20-22], improving modern technologies [23], obtaining new functional materials [24-26] and, accordingly, expanding areas of their use.

The obtained hydrogels based on copolymers of HEMA with PVP (poly(VP-gr-HEMA)) draw attention by elasticity, resilience, sufficient porosity, high chemical and biological inertness, antithrombogenicity [9], which provides a perspective for their use as materials for vascular protheses. However, the disadvantage, which limits the use of the obtained materials for the production of vascular prostheses is their insufficient strength characteristics, as well as the lack of technology production of protheses.

It has been established that one of the methods of increasing the strength characteristics of the products based on polymer hydrogels is to modify their surface by applying additional reinforced layers, for example, on the basis of interpolymer complex PA-6/PVP by using the method of diffusion precipitation from a formate solution [10].

The purpose of this work is to develop a formation method of tubular products from composite hydrogels based on copolymers poly(VP-gr-HEMA) of increased strength, which could be used as vascular prostheses.

\section{Experimental}

\subsection{Materials}

To obtain the hydrogel tubular products 2hydroxyethylmethacrylate (Sigma Chemical Co), purified and distilled in vacuum (residual pressure $130 \mathrm{~N} / \mathrm{m}^{2}$, $T_{B}=351 \mathrm{~K}$ ) was used; polyvinylpyrrolidone (AppliChem $\mathrm{GmbH}$ ) of high purity with MM 12000 was dried at $338 \mathrm{~K}$ in vacuum for 2-3 $\mathrm{h}$ before use; inorganic salts (iron(II) sulfate, silver nitrate) were of P.A. grade. Polycaproamide (PA-6) of trade mark "Tarnamid-27" and formic acid of pure grade containing the main substance of $90 \%$ were used to obtain a modifying solution. The composition of the modifying solution is as follows: (PA6/PVP): $\mathrm{HCOOH}=7: 93$ mass parts, PA-6:PVP = $=95: 5$ mass parts.

\subsection{Methods}

Synthesis of poly(VP-gr-HEMA) copolymers was carried out in the presence of $\mathrm{FeSO}_{4}$ at the temperatures of
$293-298 \mathrm{~K}$ in the air without additional vacuumization of the initial composition [27]. In order to combine the stages of synthesis of the hydrophilic polymer and its subsequent swelling, the polymerization was carried out in water. The synthesis of the hydrogel with the simultaneous formation of the tubular product occurred in a polymerization form.

To increase the mechanical strength, the hydrogel tubes were modified by a thin layer due to the diffusion precipitation of PA-6/PVP from the formic acid solution [10]. The one-sided application of a thin polyamide layer on the surface of the hydrogel tubes was carried out due to the contact of formate solution PA-6/PVP with the surface of the hydrogel sample during a certain period of time (1$10 \mathrm{~min}$ ), followed by the solvent evaporation at the temperature of $348-353 \mathrm{~K}$ for $30 \mathrm{~min}$. The obtained composite hydrogel tubes were hydrated for $24 \mathrm{~h}$ in distilled water at room temperature before the research.

Samples in the form of blocks, films and tubes in the hydrated state were used to investigate the physicomechanical characteristics of the obtained products. Deformation and elastic characteristics - the hardness number $(H, \mathrm{MPa})$ and the resilience index $(E, \%)$ - were determined using hardness meter TShR-320 by measuring the difference between the immersion depth of the indenter in the sample under the action of pre- and total load:

$$
\begin{aligned}
& H=\frac{0.1 F}{\pi \cdot d \cdot h} \\
& E=\frac{h-h_{1}}{h} \cdot 100
\end{aligned}
$$

where $F$ is an applied load, $\mathrm{N} ; d$ is a diameter of indenter ball, $\mathrm{mm}(d=5 \mathrm{~mm}) ; h$ is a depth of ball penetration into the sample under the load $\mathrm{F}, \mathrm{mm} ; h_{1}$ is a residual deformation after removing the load, $\mathrm{mm}$.

The bursting strength $(\sigma, \mathrm{MPa})$ and the percentage elongation at bursting $(\varepsilon, \%)$ of the synthesized materials were determined by a breakthrough method using the film sample fixed in a ring-shaped clip, under the action of a pin indenter, by using a tensile testing machine "Kimura" of 050/RT-6010 type with the sample strain rate of $25 \mathrm{~mm} / \mathrm{min}[10]$.

The bursting strength and percentage elongation at bursting for hydrated films have been calculated according to the following formulas:

$$
\begin{aligned}
\sigma & =\frac{F}{D \cdot h} \cdot 10^{-6} \\
\varepsilon & =257 \cdot \frac{l}{D}-25
\end{aligned}
$$

where $F$ is stress, under which the sample is destroying, N; $D$ is a diameter of ring-shaped clamp hole, $\mathrm{m} ; h$ is a film thickness, $\mathrm{m}$; $l$ is a pin transposition from moment of contact with the sample till the moment of rupture, $\mathrm{m}$ (Fig. 1). 
To study the resistance to the internal pressure of the hydrogel tubular samples, a laboratory unit was constructed (Fig. 2) and a method was developed, the essence of which is the liquid pressure fixation under which the sample is bursting. The internal pressure, fixed by using a manometer 2 , is created in a tubular sample 1 by the force of water supplied through a through-hole in the conical fitting 3 .

The film thickness was measured with a TR 10-60 thickness gauge with an accuracy of $\pm 0.01 \mathrm{~mm}$. The value of surface adsorption (A, $\mathrm{kg} / \mathrm{m}^{2}$ ) was determined as the ratio of the formed modifying layer weight to the area of the modified surface:

$$
A=\frac{\left(m_{0}-m_{1}\right)}{S}
$$

where $m_{0}$ is the initial weight of hydrogel film, $\mathrm{kg} ; m_{1}$ is the weight of the hydrogel film after application of the modifying layer, $\mathrm{kg} ; S$ is the area of the modified surface, $\mathrm{m}^{2}$.

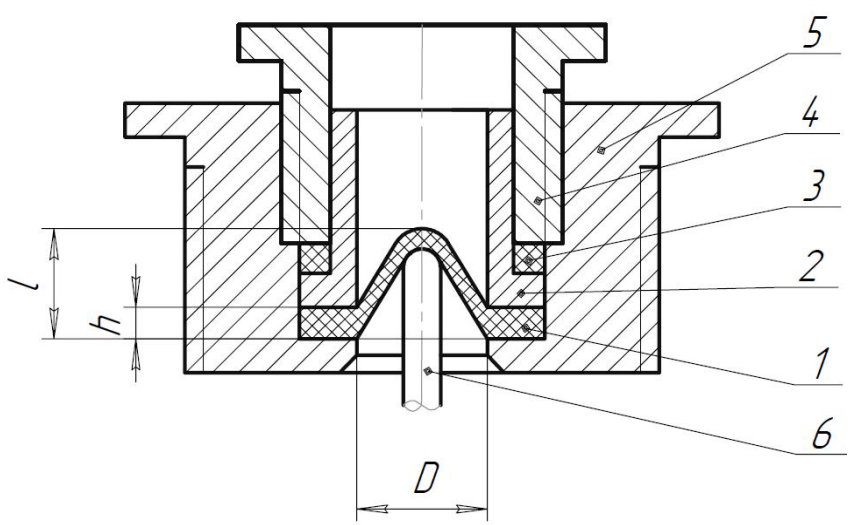

Fig. 1. Scheme of device for film materials physico-mechanical characteristics determination by bursting: 1 - film; 2 - ring-shaped clamp; 3 fluoroplastic seal; 4 - clamping nut; 5 - holder; 6 - pin

\section{Results and Discussion}

The initial HEMA/PVP/ $\mathrm{H}_{2} \mathrm{O}$ compositions are characterized by a high fluidity, which ensures the ability for them to be processed into tubes by the casting method. Hydrogel tubular products were obtained in a polymerization form, the main elements of which are the matrix and the punch (Fig. 3). In order to facilitate a product removal from the mold, the outer molding surface (matrix) was made of polypropylene, because of the adhesion of poly(VP-gr-HEMA) copolymers to it was the lowest.

The use of the developed mold with changeable molding elements ensures an obtainment of tubular products (Fig. 4) with geometric dimensions: length from 100 to $400 \mathrm{~mm}$, inner diameter - from 3 to $10 \mathrm{~mm}$, wall thickness - from 0.2 to $2 \mathrm{~mm}$.

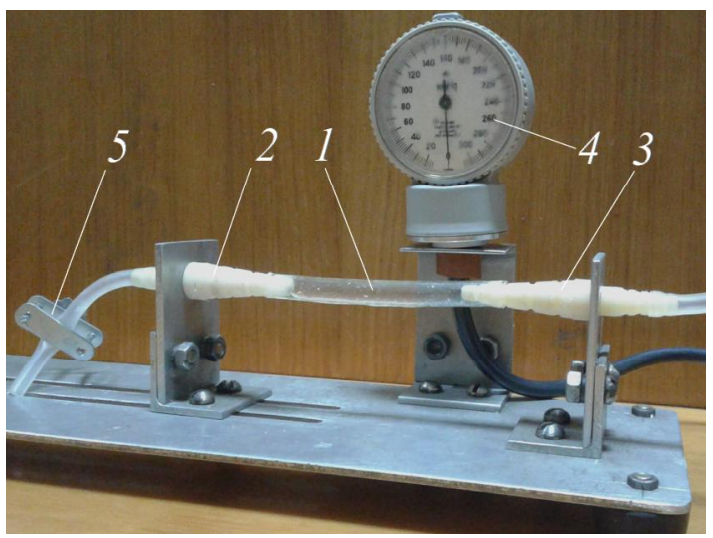

Fig. 2. Laboratory setup for investigation the resistance of hydrogel tubes to the internal pressure: 1 - tubular hydrogel sample; 2, 3 - conical fittings for fixation of a research sample; 4 - manometer; 5 - clip

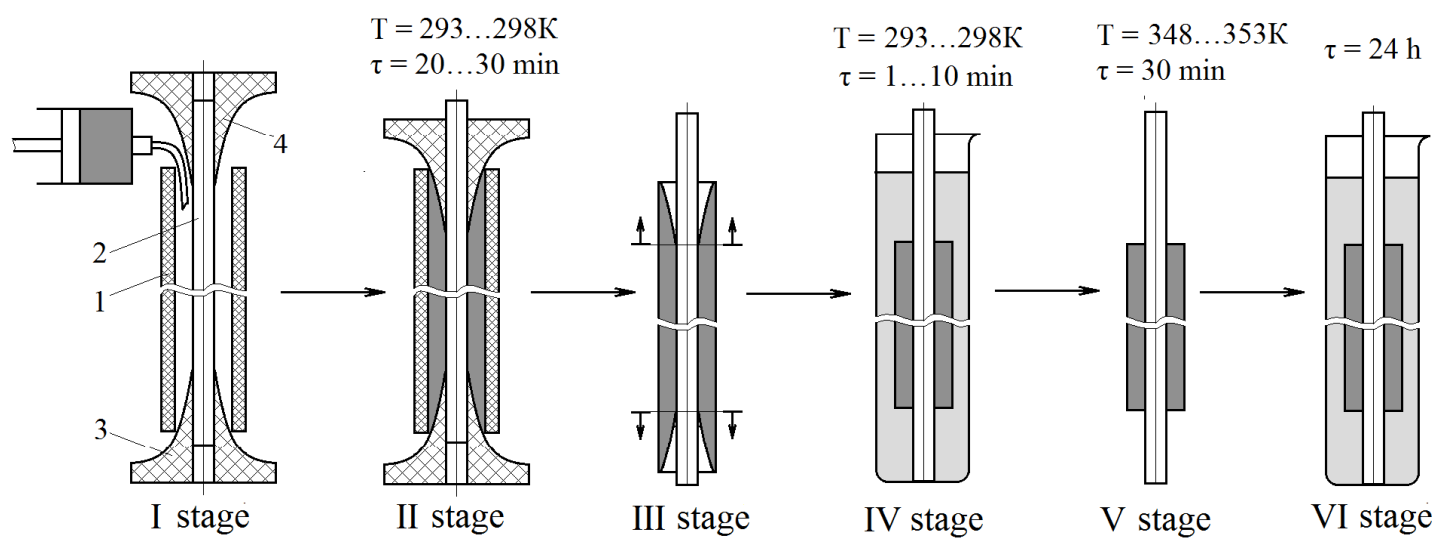

Fig. 3. Schematic diagram of two-layer hydrogel tubes obtaining. Stages: I - dosage of the composition (1 - matrix; 2 - punch; 3, 4 - calibration insert); II - polymerization; III - trimming the edges; IV - application of the modifying layer; $\mathrm{V}$ - evaporation of the solvent; VI - hydration 


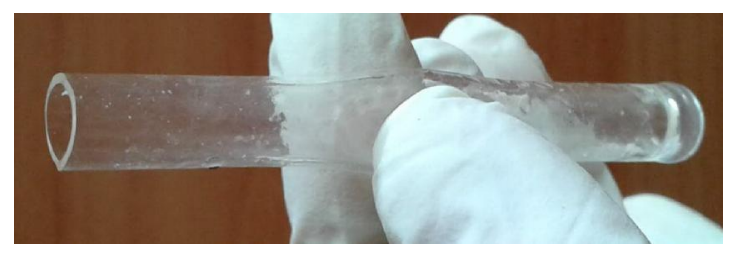

a)

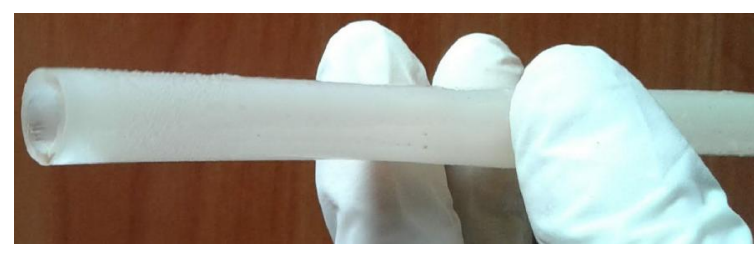

b)

Fig. 4. Tubular products based on hydrogel poly(VP-gr-HEMA) (a) and hydrogel poly(VP-gr-HEMA)+(PA-6/PVP) composite (b)

On the basis of previous studies [9, 27], HEMA with PVP copolymerization in the presence of iron(II) sulfate was used to obtain hydrogel tubes. Polymerization occurs with a high speed at room temperature, in the air, which makes it possible to significantly simplify and reduce the cost of the process, shorten its duration and extend its abilities of usage.

The compositions of the structure HEMA:PVP = $=(90-60):(10-40)$ mass parts using from 50 till 200 mass parts of the solvent $\left(\mathrm{H}_{2} \mathrm{O}\right)$ were studied. The lower limit of the PVP content is caused by the fact that with the less content of it, the hardening time of the compositions significantly increases (up to $24 \mathrm{~h}$ ). The upper limit is caused by technological complications - the higher the PVP content, the duration of its dissolution in HEMA increases, the viscosity of the composition, which is difficult to dispense and deaerate, increases as well.

The main physico-mechanical properties that determine the suitability of the polymer material for the production of vascular prostheses are strength, elasticity and resilience [1-5]. The strength of the hydrogel samples was characterized on the basis of the study results of their tensile strength during the bursting $(\sigma, \mathrm{MPa})$ and the hardness number. Resilience was estimated by the resilience index, and elasticity by a percentage elongation at bursting $(\varepsilon, \%)$.
In order to determine the composition formulation, which would provide optimal characteristics of the hydrogel tubular products, the effect of PVP and solvent content in the initial composition on the physico-mechanical properties of the hydrogels was studied (Fig. 5). The results showed that if the PVP content of the initial composition increases, the strength and resilience of the hydrogel samples decrease, while their elasticity increases, which is caused by the formation of a polymeric network with a less crosslinking degree, as well as outwashing of chemically unbound PVP, which promote an increasing of the free volume [28].

At the same time, it was found [10] that with increasing porosity of the hydrogel, the adsorption value of the modifying layer to the hydrogel substrate improves.

The relatively high strength and resilience properties with the retention of sufficiently high elasticity and surface adsorption, are characteristic for the polymer-monomer composition of the formula HEMA:PVP $==80: 20$ mass parts. Therefore, the optimal properties of the hydrogels are ensured by the water content in the initial composition within 75 mass parts. Thus, the hydrogel tubes were formed by using the initial polymer-monomer composition of the formula HEMA:PVP: $\mathrm{H}_{2} \mathrm{O}=80: 20: 75$ mass parts and an initiation system based on iron(II) sulfate.

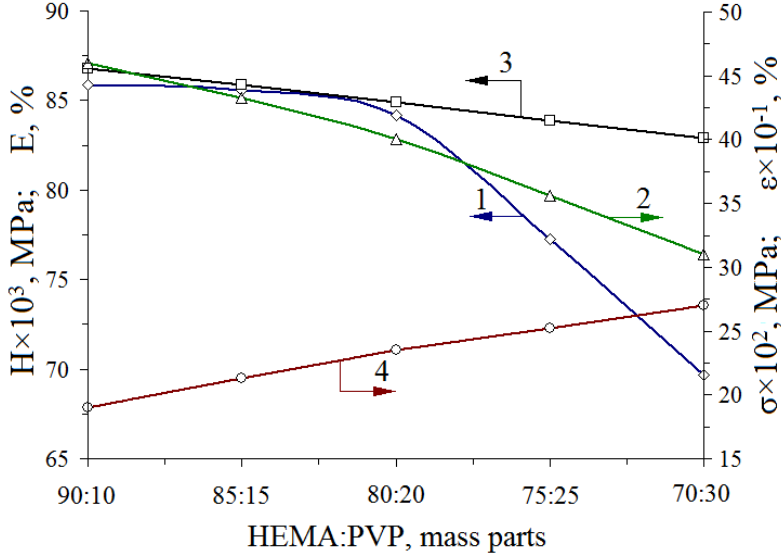

a)

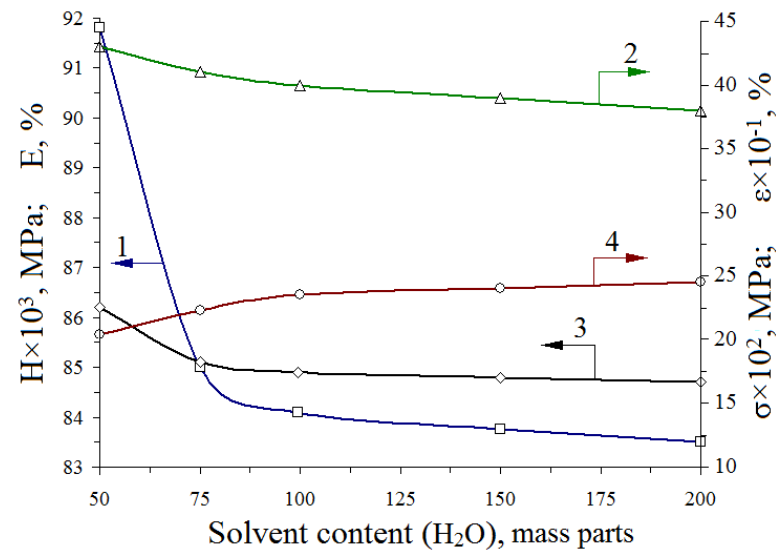

b)

Fig. 5. Dependence of hardness number $H(1)$, tensile strength during the bursting $\sigma(2)$, resilience index $E$ (3) and percentage elongation at bursting $\varepsilon(4)$ on the composition of initial HEMA:PVP (composition: $\mathrm{H}_{2} \mathrm{O}=1: 1$ ) (a) and the solvent content

(HEMA:PVP = 80:20 mass parts) (b) 
To increase physico-mechanical properties of the tubular products based on the poly(VP-gr-HEMA) hydrogels, they were modified with a thin layer of the PA6/PVP mixture, which was obtained from the formate solution by the precipitation of hydrogel free water [23]. The studies were carried out by using film samples. Certainly, the holding time of the sample in the modifying solution will affect the characteristics of the modifying layer and the composite in total. It was established [10] that holding the samples in the modifying solution positively affects the strength of the composite hydrogel. However, after $5 \mathrm{~min}$ of modification, the resilience and elasticity of the composites deteriorate sharply. At the same time, it was investigated that the holding duration of the hydrogel film samples in the modifying solution has a positive effect on the surface adsorption value of the mixture PA-6 with PVP (Fig. 6).

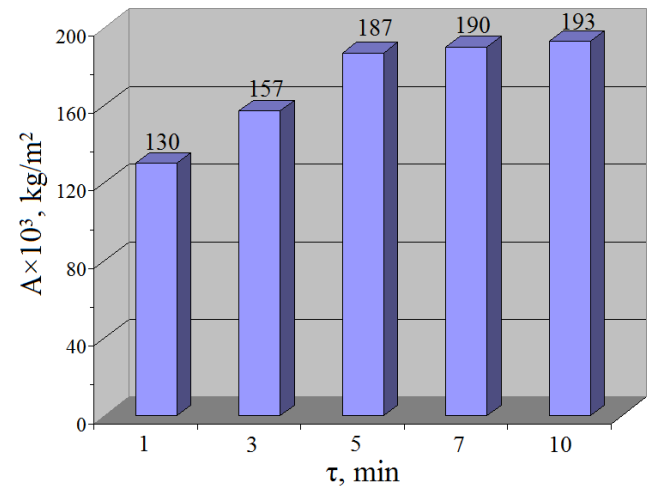

Fig. 6. Surface adsorption of PA-6/PVP mixture from formic acid solution on modification time of hydrogel films

(HEMA:PVP: $\mathrm{H}_{2} \mathrm{O}=$ 80:20:75 mass parts)

It was found that the adsorption of the reinforced layer to the hydrogel substrate increases straight-linearly during the first $5 \mathrm{~min}$ of holding the hydrogel sample in the modifying solution, after which the value of adsorption changes slightly. Consequently, for the subsequent studies, we establish the duration of the holding stage of the hydrogel tubes in a modifying solution for $5 \mathrm{~min}$.

Accordingly, on the basis of the conducted researches it is possible to distinguish the following main stages of the forming process of composite two-layer hydrogel tubular products (Fig. 3): dosage of the composition; polymerization; mechanical processing (trimming the edges); application of the modifying layer; evaporation of the solvent; hydration of the hydrogel tube.

On the basis of the obtained results, and by the use of the designed laboratory equipment, tubular hydrogel samples with different formulation of the initial polymermonomer composition were formed. The strength of tubular products suitable for use as vascular prostheses, further characterize the ability to withstand internal pressure. For this purpose, the studies of the resistance of the obtained hydrogel tubes to the internal pressure were carried out (Fig. 7). The results showed that the resistance to breakthrough from the internal pressure of the modified samples is almost two times higher than the strength of the unmodified ones and is within the permissible limits of blood vessel exploitation.

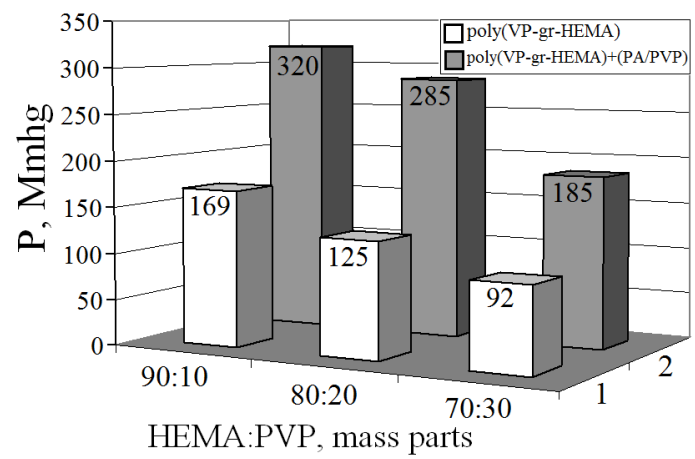

Fig. 7. Dependence of maximum bursting pressure on the composition of initial HEMA:PVP (composition:water $=1: 1$ mass parts): hydrogel tubular sample based on a copolymer poly(VP-gr-HEMA) (1) and hydrogel tubular sample based on a copolymer poly(VP-gr-HEMA)+(PA/PVP) (2)

At the same time, there is information [29] that prosthetic graft infection is one of the main complications of vascular surgery associated with high morbidity rate. The leading cause of the infection of vascular graft is contamination during the initial surgical procedure. The most common bacteria cultured from infected grafts include Staphylococcus aureus, Staphylococcus epidermidis, diphtheroids, and gram-negative enteric organisms [29].

The combination in the developed method processes of obtaining tubular products and reduction process of metal ions at the stage of polymerization [12], ensured the possibility of obtaining composite silver-filled tubular hydrogels with bactericidal and antifungal properties, which is confirmed by medico-biological studies on the examples of tested bacterial cultures: Escherichia coli (E. coli), Staphylococcus aureus ( $S$. aureus), Staphylococcus epidermidis (S. epidermidis), Streptococcus viridans (Str. viridans) and diploid fungus Candida albicans (C. albicans).

Table

\section{Bactericidal and antifungal activity of silver-filled hydrogel tubes, obtained on the basis of HEMA copolymers with PVP}

\begin{tabular}{|c|c|c|c|c|}
\hline \multicolumn{5}{|c|}{$\begin{array}{c}\text { Magnitude of the zone of inhibition } \\
\text { of microorganism growth, mm }\end{array}$} \\
\hline S. aureus & S. epidermidis & Str. viridans & E. coli & C. albicans \\
\hline $12,10,9$ & $12,8,9$ & $11,11,9$ & $3,3,0$ & $11,11,7$ \\
\hline
\end{tabular}


Due to the comparative analysis of bactericidal and antifungal properties of unfilled and $\mathrm{Ag}(0)$-filled hydrogels concerning the microorganisms usage, it was found that unfilled hydrogels do not exhibit bactericidal and antifungal properties. At the same time, materials containing $\operatorname{Ag}(0)$ block the growth of bacteria and fungi (Table).

\section{Conclusions}

The peculiarities of the forming technology of composite double-layer hydrogel tubes on the basis of liquid-structured copolymers of 2-hydroxyethylmethacrylate with polyvinylpyrrolidone, which were strengthened with a layer of polymer mixture of polycaproamide/ polyvinylpyrrolidone, have been studied. Tubular hydrogel products with the increased strength and with the ability to provide bactericidal and antifungal properties were obtained.

The proposed technology is easy to implement into production and does not require sophisticated hardware design. Such technology is a priority and needs the development, considering the perspective of the obtained products.

The obtained composite double-layer hydrogel tubes with the increased strength are recommended for further preclinical studies for the possibility of use as blood vessel prostheses.

\section{References}

[1] Popova I., Stepanova A., Sergeevichev D. et al.: Patologiya Krovoobrashcheniya i Kardiokhirurgiya, 2015, 19, 63.

[2] Khlif H., Ben Abdessalem S., Dhouib S., Sakli F.: Trends Appl. Sci. Res., 2011, 6, 1019. https://doi.org/10.3923/tasr.2011.1019.1027 [3] Marzougui S., Abdessalem S., Sakli F.: J. Appl. Sci., 2009, 9, 2794. https://doi.org/10.3923/jas.2009.2794.2800

[4] Grasl C., Bergmeister H., Stoiber M. et al.: J. Biomed. Mater. Res., 2010, 93, 716. https://doi.org/10.1002/jbm.a.32584

[5] Chlupác J., Filová E., Bacáková L.: Rozhledy, 2010, 89, 85.

[6] Khan S., Ullah A., Ullah K., Rehman N.: Des. Monomers Polym., 2016, 19, 456. https://doi.org/10.1080/15685551.2016.1169380 [7] Jumadilov T., Abilov Z., Kondaurov R. et al.: Chem. Chem. Technol., 2015, 9, 459. https://doi.org/10.23939/chcht09.04.459

[8] Gibas I., Janik H.: Chem. Chem. Technol., 2010, 4, 297.

[9] Suberlyak O., Skorokhoda V.: Hydrogels based on

polyvinylpyrrolidone copolymers [in:] Haider S. and Haider A. (Eds.), Hydrogels. IntechOpen, London 2018, 136-214.

https://doi.org/10.5772/intechopen.72082

[10] Suberlyak O., Baran N., Melnyk Y., Yatsulchak G.: Voprosy

Khimii i Khimicheskoi Tekhnologii, 2018, 3, 121.

[11] Skorokhoda V.: Chem. Chem. Technol., 2010, 4, 191.

[12] Grytsenko O., Pokhmurska A., Suberliak S. et al.: East.-Eur. J. Enterprise Technol., 2018, 6/6, 6. https://doi.org/10.15587/17294061.2018.150690

[13] Montheard J., Chatzopoulos M., Chappard D.: J. Macromol. Sci., 1992, 32, 1. https://doi.org/10.1080/15321799208018377
[14] Yanez F., Concheiro A., Alvarez-Lorenzo C.: Eur. J. Pharm.

Biopharm., 2008, 69, 1094. https://doi.org/10.1016/j.ejpb.2008.01.023

[15] Malešić N., Rusmirović J., Jovašević J. et al.: Tehnika, 2014, 69,

563. https://doi.org/10.5937/tehnika1404563M

[16] Prasitsilp M., Siriwittayakorn T., Molloy R. et al.: J. Mater. Sci.Mater M., 2003, 14, 595. https://doi.org/10.1023/A:1024066806347

[17] Teodorescu M., Bercea M.: Polym.-Plastic Technol. Eng., 2015, 54, 923. https://doi.org/10.1080/03602559.2014.979506

[18] Reverberi A., Salerno M., Lauciello S., Fabiano B.: Materials, 2016, 9, 809. https://doi.org/10.3390/ma9100809

[19] Koczkur K., Mourdikoudis S., Polavarapu L., Skrabalak S.:

Dalton Transact., 2015, 44, 17883.

https://doi.org/10.1039/C5DT02964C

[20] Fan M., Zhang L., Wang R. et al.: Appl. Clay Sci., 2017, 144, 1. https://doi.org/10.1016/j.clay.2017.04.022

[21] Suberlyak O., Krasins'kyi V., Shapoval I, Hrytsenko O.: Mater. Sci., 2011, 46, 669. https://doi.org/10.1007/s11003-011-9339-z

[22] Suberlyak O., Krasinskiy V., Sikora J., Krzyzak A.: Chem.

Chem. Technol., 2012, 6, 199.

https://doi/org/10.23939/chcht06.02.199

[23] Suberlyak O., Baran N., Yatsul'chak H.: Mater. Sci., 2017, 53, 392. https://doi.org/10.1007/s1 1003-017-0087-6

[24] Suberlyak O., Grytsenko O., Hischak K., Hnatchuk N.: Chem. Chem. Technol., 2013, 7, 289.

https://doi/org/10.23939/chcht07.03.289

[25] Roy N., Saha N.: PVP-based Hydrogels: Synthesis, Properties and Applications [in:] Câmara F., Ferreira L. (Eds.), Hydrogels: Synthesis, Characterization and Applications. Nova Science, Hauppauge, NY 2012, 227-252.

[26] Grytsenko O., Naumenko O., Suberlyak O. et al.: Voprosy Khimii i Khimicheskoi Tekhnologii, 2020, 1, 25. https://doi.org/10.32434/0321-4095-2020-128-1-25-32

[27] Suberlyak O., Grytsenko O., Kochubei V.: Chem. Chem.

Technol., 2015, 9, 429. https://doi.org/10.23939/chcht09.04.429

[28] Suberlyak O., Hrytsenko O., Hischak Kh.: Mater. Sci., 2016, 52,

155. https://doi.org/10.1007/s11003-016-9938-9

[29] Sousa J., Antunes L., Mendes C. et al.: Angiologia e Cirurgia

Vascular, 2014, 10, 52. https://doi.org/10.1016/S1646-

$706 \times(14) 70050-3$

Received: May 02, 2019 /Revised: May 14, 2019 / Accepted: July 12, 2019

\section{ОСОБЛИВОСТІ ФОРМУВАННЯ ТРУБЧАТИХ ВИРОБІВ НА ОСНОВІ КОМПОЗИЦІЙНИХ ГІДРОГЕЛІВ}

\begin{abstract}
Анотація. Розроблений метод одержання композиційних гідрогелевих трубчатих виробів підвищеної міџності на основі кополімерів 2-гідроксіетилметакрилату з полівінілпіролідоном. Метод полягає у формуванні гідрогелевих трубок з наступним осадженням з розчину у їх зовнішню поверхню зміцнювального шару на основі поліаміду, модифікованого полівінілпіролідоном. Одержані композиційні гідрогелеві трубки, які відзначаються достатньою міцністю, пружністю, еластичністю, а також здатністю витримувати внутрішній тиск в межах 24-43 кПа (180-320 мм.рт.ст.).
\end{abstract}

Ключові слова: гідрогелі, гідрогелеві композити, поліамід, полівінілпіролідон, судинні протези. 